\title{
The New in the New Religious Movements among Zulu and Swazi
}

\author{
By BENGT SUNDKLER
}

\section{SUMMARY}

What was new in the Early Christian Church? Is it not a fact that continuity with the Old Testament background dominated? The first Christians were Jews; their Holy Book was the "Old" Testament; they honoured the Torah; and felt at the Sabbath at home in the Temple. All this goes to show that nothing, perhaps, was new.

Yet, to the early Christians everything was, in fact, new. "Old things are passed away: behold, all things are become new". 2 Cor. 5: 17.

This same tension can be discerned in the modern Christian prophet movements in Africa.

All of us who have tried to interpret aspects of this movement were intent on proving that what was new was in fact-the Old. We demonstrated how within the apparently Christian Church the old traditional African patterns showed through and dominated. If "magic" was found to have been smelled out, this was mentioned only in order to show how the particular group was dominated by fear of magic. In studying the "blend of old and new' in the movements it was easy to suggest that the interesting aspect was role of traditional values, dressed up in new forms.

In our own Bantu Prophets in South Africa, 1st edition of 1948, we concluded in somewhat generalizing terms that certain Independent Churches had indeed been turned into "a bridge to the past". Yet, in the second edition of the same book-of 1960-we were prepared to make amends in that the "bridge" was turned not so much to the past, as to the future.

To the founder of a particular Independent Church, and to his/her followers, the overwhelming experience was one of a fresh start and of a totally new beginning.

The revelation imparted to the prophet became the fundamental dogma of the Church, from which it counted its new departure, to be referred to in 
liturgy and homily: that Timothy Cekwane was born as a result of a drop of blood from Heaven inserted in his mother's womb; that George Khambule had "died" and "risen", receiving in heaven special instructions from Lord Jesus; that Paulo Nzuza had received the Holy Spirit on May 9, 1916, second only to that other Paul, Saula Paula-or St Paul-who several years earlier had had a similar experience; that Isaiah Shembe as a young man on a mountain had "seen Jehova". This made them all into men apart, prophets with a special revelation. This revelation accounts for the influence of the prophet's personality. I have been impressed by the immense "weight of personality" in some of these leaders.

In a divided and torn society of apartheid and discrimination, the new Church gave the uprooted individual what he was looking for: a new identity. The rite de passage of "baptism in much water", or in "living water"; the new uniform-white as a sign of holiness and blue, for heaven-the new name; these were different signs that in many cases had already been anticipated by the individual through his/her dream as the ordinary individual's interiorisation of the revelation given unto the Prophet.

The "newness" of these experiences was of course not a calculated or engineered innovation, as if the prophet had been selecting certain aspects in order to achieve something new. It was rather an expression of an overwhelmingly new religious experience, of a reality of a more intense kind and quality than these people had hitherto had. It was an experience that engaged the whole man and it often had to be expressed in new linguistic forms of glossolaly.

As a matter of course there were contacts with the traditional past. In crises of illness and death the old influence of the isangoma will assert itself. There is a certain give-and-take between traditional forms and those of the so-called "Zionist" churches. An interesting recent example was the burial of a Swazi isangoma; the rites on the occasion were obviously influenced by modern Zionist practices.

Among factors, introducing newness must, on the other hand, be mentioned a) The new Fellowship of healing, worship, and, faith in the Church. An overwhelming number of ordinary members joined the Church in a crisis of illness, and it is, for a time, recognized that the Zion group provides what it promises to give: health and wholeness. The liturgical and social fellowship contributes to produce that new "in-group" feeling which has an integrating effect also on the individual. 
b) The role of the African church leader. There is going on a continuous imitation of, and thereby identification with, the Prophet. Thus, for instance, his/her mannerisms are copied: a jerking movement, a special verbal expression are repeated by the individual member in new generations. Thereby a process is followed which is felt as strengthening the new identity of the individual.

c) Certain church festivals, especially "iGoodi", or the Good FridayEaster festival with its vigils are occasions when the members identify with the Passion of Christ. There is intense meditation on the Golgotha drama and its parallel in the fate of South African Blacks. The central core of the New Testament message is reenacted and appropriated by the group. In this connection, the role of the Holy Book, the Bible, particularly its apocalyptic passages, must be stressed.

Sometimes these churches have been referred to as "Messianic". The term needs to be clearly defined. First of all, it is a term that must not be forced upon the great majority of these churches. Only in the case of about $1 \%$ of the 1500 Zionist groups can one suggest the application of this term. Also in the case of this select residuum, the term is now resented, by a second generation of Church leaders, as "blasphemy'" and as a terminological aggression on the part of Western scholars.

We suggest in its place the introduction of the term "eiconic", with its double background in African ànd in New Testament terminology (1.2 Cor; Col.) the mask.

Is this then a new form of syncretism? This much, at least, can be said. It is not a conscious, studied effort at a mixture of old and new. As we have tried to indicate, old patterns will as a matter of course assert themselves. But this is not specific for this particular African situation. Intentionally, the Black Zionist in Zululand or in Swaziland felt that he was building something new, on Biblical foundations, leading his flock towards a new Promised Land. 